\title{
Symbolic equids and Kushite state formation: a horse burial at Tombos
}

\author{
Sarah A. Schrader ${ }^{1, *}$, Stuart Tyson Smith ${ }^{2}$, Sandra Olsen ${ }^{3}$ \\ $\&$ Michele Buzon ${ }^{4}$
}

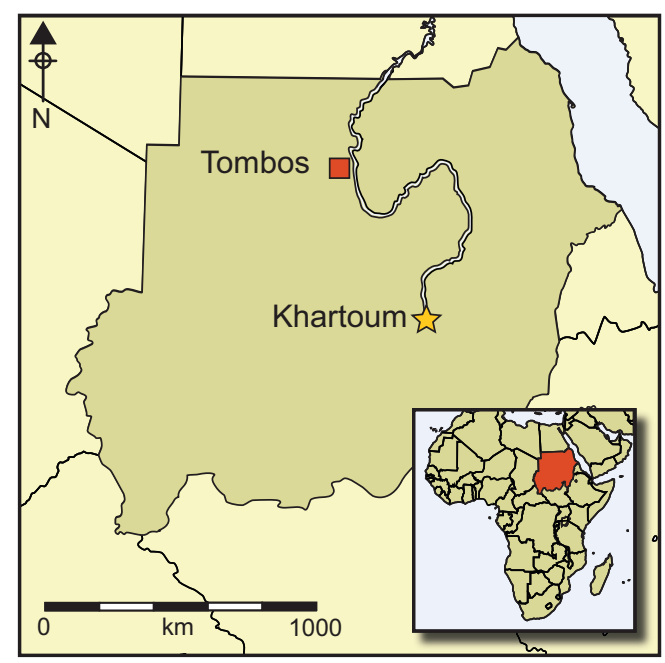

The recent discovery of a well-preserved horse burial at the Third Cataract site of Tombos illuminates the social significance of equids in the Nile Valley. The accompanying funerary assemblage includes one of the earliest securely dated pieces of iron in Africa. The Third Intermediate Period (1050-728 BC) saw the development of the Nubian Kushite state beyond the southern border of Egypt. Analysis of the mortuary and osteological evidence suggests that horses represented symbols of a larger social, political and economic movement, and that the horse gained symbolic meaning in the Nile Valley prior to its adoption by the Kushite elite. This new discovery has important implications for the study of the early Kushite state and the formation of Kushite social identity.

Keywords: Sudan, Egypt, Nile Valley, Napata, Kushite, horse, iron

The relationship between humans and animals is highly complex. When animals are viewed as more than a basic source of nutrition, they become ritual objects, symbolic beings and companion pets. Recent archaeozoological research has begun to conceptualise these interconnected human-animal relationships in the ancient past (O'Day et al. 2004; deFrance 2009; Russell 2012; Arbuckle \& McCarty 2014). Horses (Equus caballus) can be examined from this theoretically informed perspective. Although much research has focused on their domestication and proliferation, the social role that horses played in the ancient world was certainly an important one (Argent 2010; Olsen \& Culbertson 2010). Here we present new

\footnotetext{
Leiden University, Faculty of Archaeology, P.O. Box 9515, 2300 RA Leiden, the Netherlands

University of California, Santa Barbara, Department of Anthropology, Santa Barbara, CA 93106, USA

3 The University of Kansas, Biodiversity Institute and Natural History Museum, 1345 Jayhawk Boulevard, Lawrence, KS 66045, USA

4 Purdue University, Department of Anthropology, 700 W. State Street, West Lafayette, IN 47907, USA

*Author for correspondence (Email: s.a.schrader@arch.leidenuniv.nl)
} 
Table 1. Nile Valley chronology (Smith 2013: 87).

\begin{tabular}{llll}
\hline $\begin{array}{l}\text { Egyptian } \\
\text { dynasty }\end{array}$ & Egypt & Nubia & BC \\
\hline & & & $2050-1650$ \\
$11-13$ & Middle Kingdom & & $1650-1550$ \\
$14-17$ & Second Intermediate Period & Kerma state & $1550-1050$ \\
$18-20$ & New Kingdom & Egyptian empire & $1050-728$ \\
$21-24$ & Third Intermediate Period & Early Napatan & $728-657$ \\
25 & Kushite Dynasty & Napatan state & \\
\hline
\end{tabular}

data on a horse that was interred at Tombos in the Sudan, along with one of the earliest examples of iron in Africa. These important finds are contextualised within a discussion of the history and symbolic significance of the horse in the ancient Nile Valley (Figure 1).

The horse found at Tombos, which dates from the early Napatan Period (equivalent to the Third Intermediate Period in Egypt, see Table 1), is in excellent condition and is arguably the most complete horse skeleton found in the pre-Graeco-Roman Nile Valley. Radiocarbon tests confirm the interesting temporal context of the Tombos horse $(949 \pm 55$ BC). Directly following the decline of the Egyptian New Kingdom, the Third Intermediate Period is characterised by economic growth, political unification and social transformation in Nubi, while the Kushite state emerged. In this complex milieu, the horse was not only a functional instrument of warfare and transportation, but also an ideological symbol and a self-renewing source of social and economic capital. Horses became increasingly important during the subsequent Napatan Period, during which Nubians gained an international reputation for being skilled horse trainers/breeders. Horses were a prominent feature in the artistic decoration of royal temples, and sacrificial horse burials were included in the royal cemetery. We propose that local Third Intermediate Period Nubians embraced the horse as a cultural icon and, along with other social practices and beliefs (e.g. clothing, artwork, religious deities), integrated them into a reworked, reimagined and reinvented social identity—centuries before the horse was adopted by the Kushite state.

\section{The horse in the Nile Valley}

The chronology and dynamics surrounding the introduction of the domesticated horse into the Nile Valley are the subjects of debate (see online supplementary material (OSM); SäveSöderbergh 1951; Mallory-Greenough 2005; Raulwing \& Clutton-Brock 2009). Many have credited the Hyksos, an ethnic group that settled in the Nile Delta prior to $1650 \mathrm{BC}$, with bringing the first horses into Egypt (Clutton-Brock 1974; Littauer \& Crouwel 1985; Boessneck \& von den Driesch 1992). Certainly by the New Kingdom, horses were being actively used in Egyptian armies. Spalinger (2005) suggests that the reorganisation of the ancient Egyptian military, namely the transition from the highly regarded naval command of the Middle Kingdom to the swift and adept army of the New Kingdom, allowed Egypt to conquer Syria/Palestine and colonise Nubia (1550-1425 BC). Horses would only rarely have been ridden. Rather, they would have pulled a chariot carrying a driver and a soldier armed with a composite bow (Spalinger 2005). Moreover, horses were not used as pack (C) Antiquity Publications Ltd, 2018 


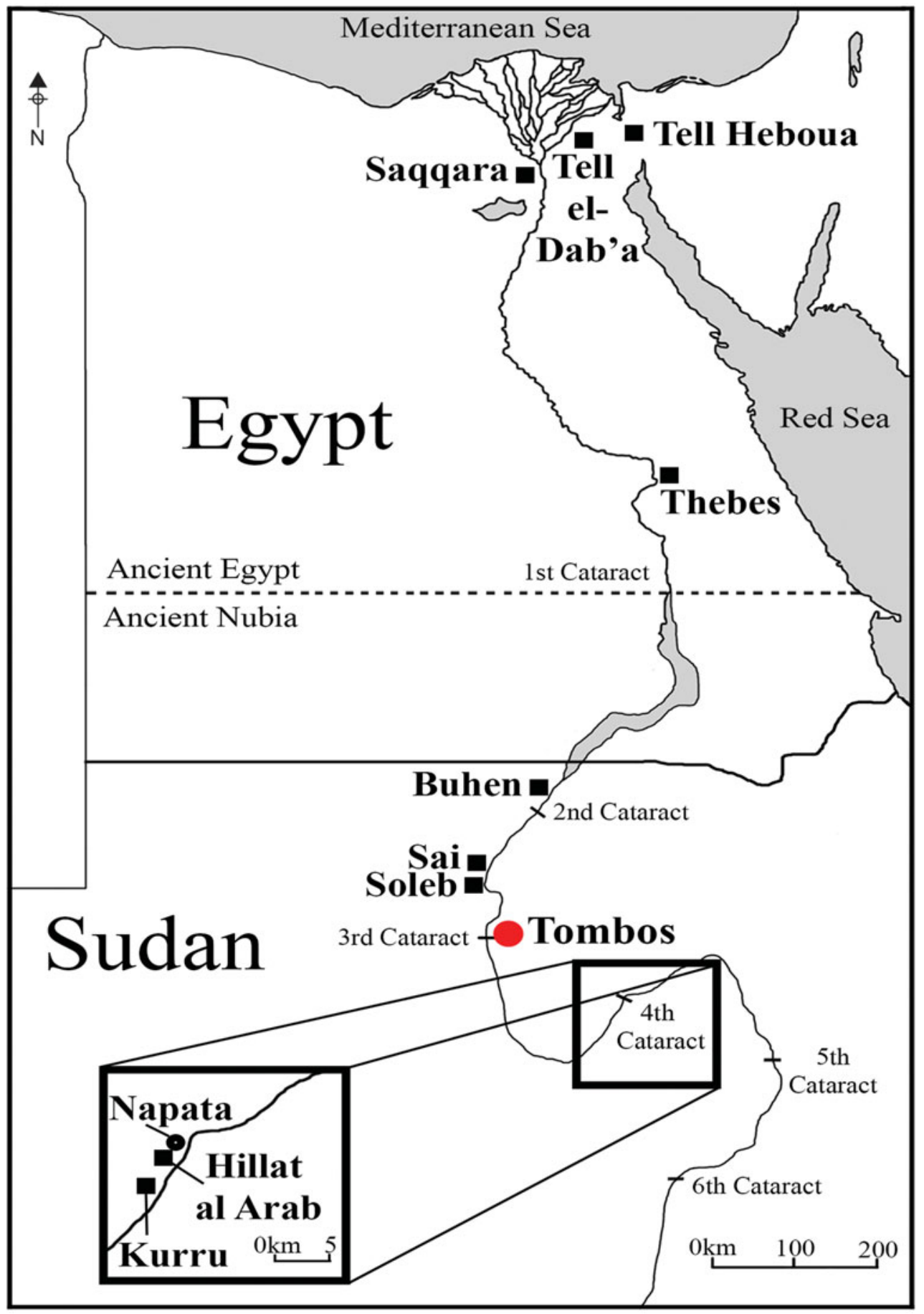

Figure 1. Map of second-to first-millennia BC horse burials in the Nile Valley: $\mathbf{\square}=$ horse burials, in addition to Tombos; - = places of interest. 


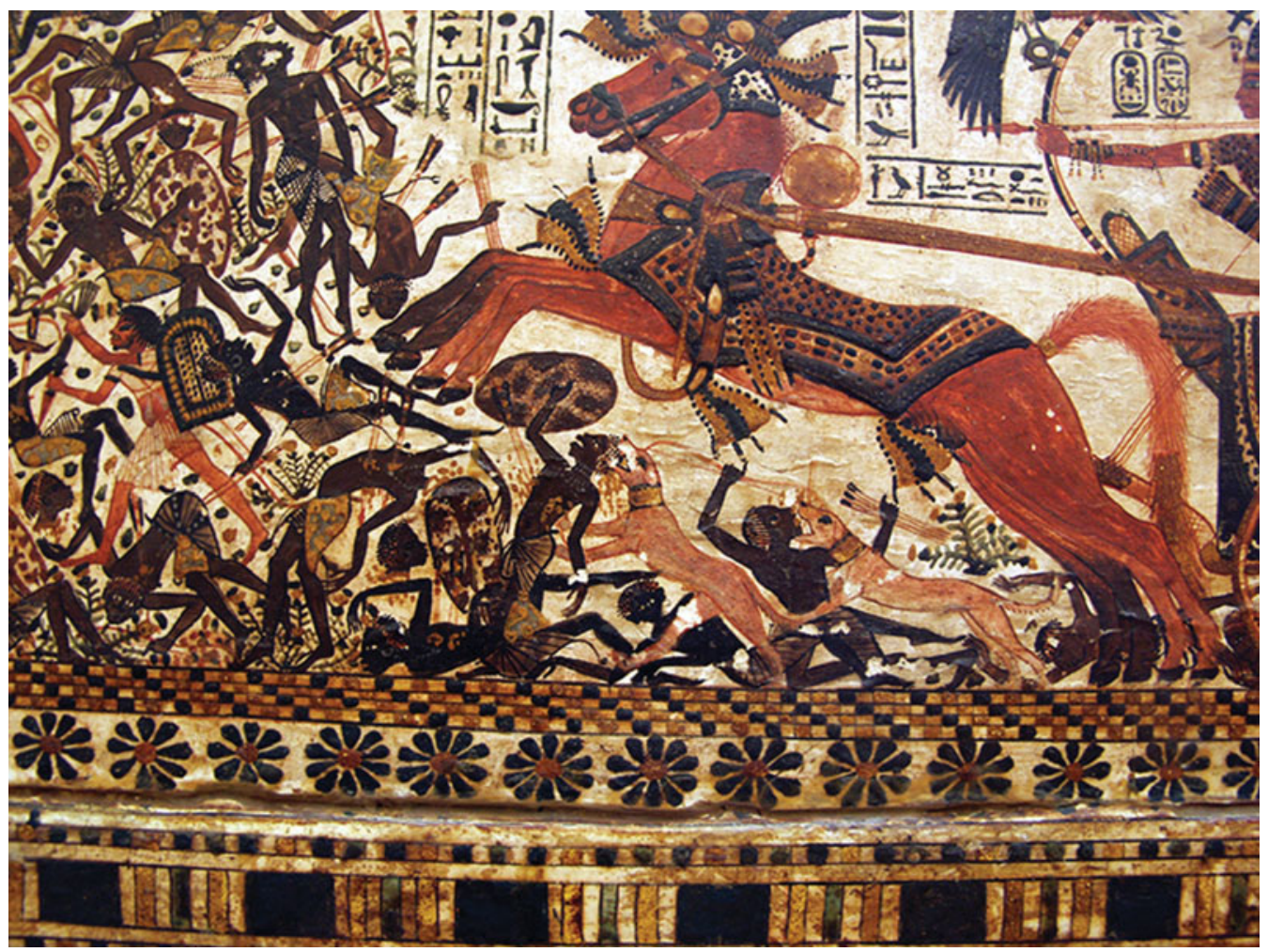

Figure 2. Chariot horses from Tutankhamen's decorated box (Egyptian Museum, Cairo).

or everyday draft animals; instead, donkeys and oxen were the preferred beasts of burden. In New Kingdom art, horses are depicted in elite and military roles, such as hunting wild fauna and engaging in battle (Littauer \& Crouwel 1985; Spalinger 2005; Olsen 2006). A wooden chest from the tomb of Tutankhamen, for example, depicts the Pharaoh, armed with a composite bow, in a two-horse chariot, hunting wild animals and trampling Egypt's Asiatic and Nubian enemies (Figure 2). The burial context of New Kingdom horses varied widely (Figure 1; see too the OSM). Some were seemingly not afforded formal burial and were deposited whole in debris or amongst other fauna in refuse deposits (e.g. Buhen, Tell el Dab'a). Others were interred with funerary ceremony (e.g. shroud and coffin at Saqqara, burial atop reed mat also at Saqqara, and shroud and coffin at Thebes) (Quibell \& Olver 1926; Chard 1937; Boessneck 1970; Clutton-Brock 1974; Boessneck 1976).

The New Kingdom became increasingly fragmented and less is known about the subsequent Third Intermediate/early Napatan Period, when the Nubia colony split away from Egypt. At one point, Nubia was thought to be abandoned. Evidence from Tombos and other contemporaneous sites, including Amara West, however, suggests that Nubian communities continued to thrive after the New Kingdom empire dissolved (Smith 2008; Spencer 2014). Horse burials contemporaneous to that at Tombos have been excavated at Hillat al-Arab, although the poor preservation of these remains makes interpretation difficult (Chaix 2006). That the Hillat al-Arab horses were interred in wealthy tombs (C) Antiquity Publications Ltd, 2018 
alongside humans suggests that the animals were significant, and this foreshadows the increasing importance of horses later in Nubian history (Chaix 2006: 188).

After the coronation at Thebes in $743 \mathrm{BC}$ of Piankhi as King of Upper and Lower Egypt, the Kushite royal lineage, centred at Napata, ruled Egypt as the Twenty-Fifth Dynasty (Edwards 2004). Piankhi cemented his control over all Egypt in 727 BC, after quelling a rebellion led by rival dynasts in the Nile Delta (Morkot 2000). The remains of 24 horses were found at the Kushite royal cemetery of el Kurru, adorned with decorative and ornate trappings, such as silver plume holders, amulets and multiple strands of beads (Dunham 1950). These horses have been interpreted as sacrifices to four Twenty-Fifth Dynasty Napatan kings: Piankhi (for a time incorrectly read as Piye, 743-712 BC), Shabaka (712-698 BC), Shebitka (698-690 BC) and Tanwetamani (664-653 BC) (Bökönyi 1993; Lenoble 1994; Rilly 2001; Mallory-Greenough 2005). Horses are a prominent feature of Piankhi's victory stela, and decorate the walls of his temple at Gebel Barkal (Morkot 2000); some of the horses are depicted with mounted cavalry, which were only rarely shown in the New Kingdom (Spalinger 1981; Török 2002; Raulwing \& Clutton-Brock 2009). Similarly, a horseback rider is portrayed in relief at the temple of Taharqa at Kawa (Macadam 1955). Contemporaneous Assyrian texts attest to the quality and superiority of Nubian horses and document them as gifts, booty, trade and tribute (Dalley 1985; Heidorn 1997; Morkot 2000). Collectively, these lines of evidence indicate that horses were highly prized during the Napatan Period, and illustrate the important role that they played in the economy, international relations, warfare and royal prestige. The Tombos horse, dating to the obscure Third Intermediate Period, helps elucidate the genesis of reverence for horses that was established by the Napatan Period.

\section{The Tombos horse}

Tombos was established during the New Kingdom (c. 1450 BC) as an Egyptian administrative centre in Nubia. It is located at the Third Cataract of the Nile and served as the southernmost point of direct imperial control. Beyond the Third Cataract, control of territories up to the Fifth Cataract was largely indirect. Although some sort of Egyptian investment is reflected in the construction of temples at Kerma, Tabo, Kawa and Gebel Barkal, the entire region upstream of the Third Cataract lacks evidence for the largescale colonisation and 'Egyptianisation' seen to the north. Additionally, commemorative inscriptions marked Tombos as a symbolic internal boundary within the empire, the last of a string of colonies placed between the Second and Third Cataracts (Morkot 2000: 129-36, 2013: 914-19; Smith 2003: 88-96, 2013). Bioarchaeological evidence indicates that both Egyptians and Nubians peacefully inhabited Tombos and that they probably intermarried (Buzon 2006). The cemetery is dominated by Egyptian-style burials (i.e. supine burial position, coffins, pyramid tombs). Traditional Nubian burial practices (i.e. flexed burial position, burial beds), however, persist through the colonial period (Smith 2003). Rather than outright acculturation and Egyptianisation of indigenous Nubians, as was once assumed, the continuation of Nubian funerary practices suggests a more complicated scenario of cultural entanglement and resistance (Smith 2013). 
Excavations at Tombos indicate that the cemetery was in use throughout the Third Intermediate and Napatan Periods (Smith 2008). While there is a continuation of select Nubian traditions, such as tumulus burial structures (mounds demarcated by stones), some individuals maintain elements of Egyptian burial practices (e.g. the continued use of pyramids, mummification, coffins, supine burial position). This suggests that there was a strong expression of multivocality at Tombos, as long-term remembrances of ancient Nubian burial practices continued throughout the colonial New Kingdom, forming a pluralistic milieu in the Third Intermediate and Napatan Periods (Smith \& Buzon 2014; Buzon et al. 2016). The Tombos horse burial can be placed within this larger cultural context as a particularly complex entanglement between Nubians, Egyptians and the Hyksos (who introduced ceremonial horse burial). The horses were brought to Egypt by the Hyksos, and later transmitted to Nubia via Egypt after the New Kingdom conquest. The practice of horse burial probably also passed into Nubia via Egyptian influence, as seen in burials at New Kingdom colonial centres such as Sai and Soleb, and perhaps during the early Napatan Period by local elites at Hillat el-Arab. This practice would have resonated with Nubia's long tradition of ceremonial animal burial. The Tombos horse provides further evidence for the continuation of the practice after the withdrawal of the colony from Egyptian control.

The Tombos horse was excavated in 2011 from the shaft of a pyramid tomb that was originally constructed during the New Kingdom. The tomb complex consisted of a pyramid and chapel superstructure, with a shaft and burial chamber substructure. This tomb design was typical of elite New Kingdom pyramid tombs (Figure 3; Badawy 1968; Martin 1991; Smith 2003). The chapel, directly in front of the pyramid, would have been used for religious ceremony and remembrance, whereas the pyramid would have served as a placemarker and iconic symbol of Egyptian ethnicity, elite identity and rebirth (Smith \& Buzon 2014). Underground, the shaft extended $\sim 6 \mathrm{~m}$ directly below the chapel. At the base of the shaft, two burial chambers were carved into the bedrock, one to the east and one to the west (Figure 3, chambers A and B). These burial chambers contained multiple human inhumations, and were probably used over multiple generations (Smith 2003; Buzon et al. 2016). A scarab inscribed with the name of Ramesses II (1279-1213 BC), found at the lowest locus of the eastern chamber (A), and pottery from the bottom of the shaft and entrance to the western chamber (B) suggest that the tomb was built in the later New Kingdom, but was reused during the Third Intermediate Period.

The horse was found within the tomb shaft $1.65 \mathrm{~m}$ below the surface. It was in situ, fully articulated and intentionally positioned (Figure 4). Some chestnut-coloured fur was preserved with white 'socks' on the shanks (rear lower hind legs). The remains of decayed fabric adhering to the horse suggests the presence of a burial shroud (2838 $\pm 53 \mathrm{BP}$ ). Calibrated radiocarbon results taken from remnants of this linen shroud indicate a date of $2786 \pm 22$ cal BP; D-AMS 017601: calibrated to $1005-893 \mathrm{BC}$ at $95.4 \%$ and $874-851$ BC at 4.5\%; using OxCal v4.3, intCal 13; Bronk Ramsey 2009; Reimer et al. 2013, placing the horse burial in the early Third Intermediate Period. A scarab incised with an image of the god Ptah, facing the Ba's (souls) of Re and Osiris, was associated with the horse (Figure 5). Ben-Tor's (1989: 65) dating of this motif to the Ramesside Period (c. 1270$1070 \mathrm{BC}$ ) is not problematic, as the heavy wear on the back is consistent with an heirloom.

(C) Antiquity Publications Ltd, 2018 


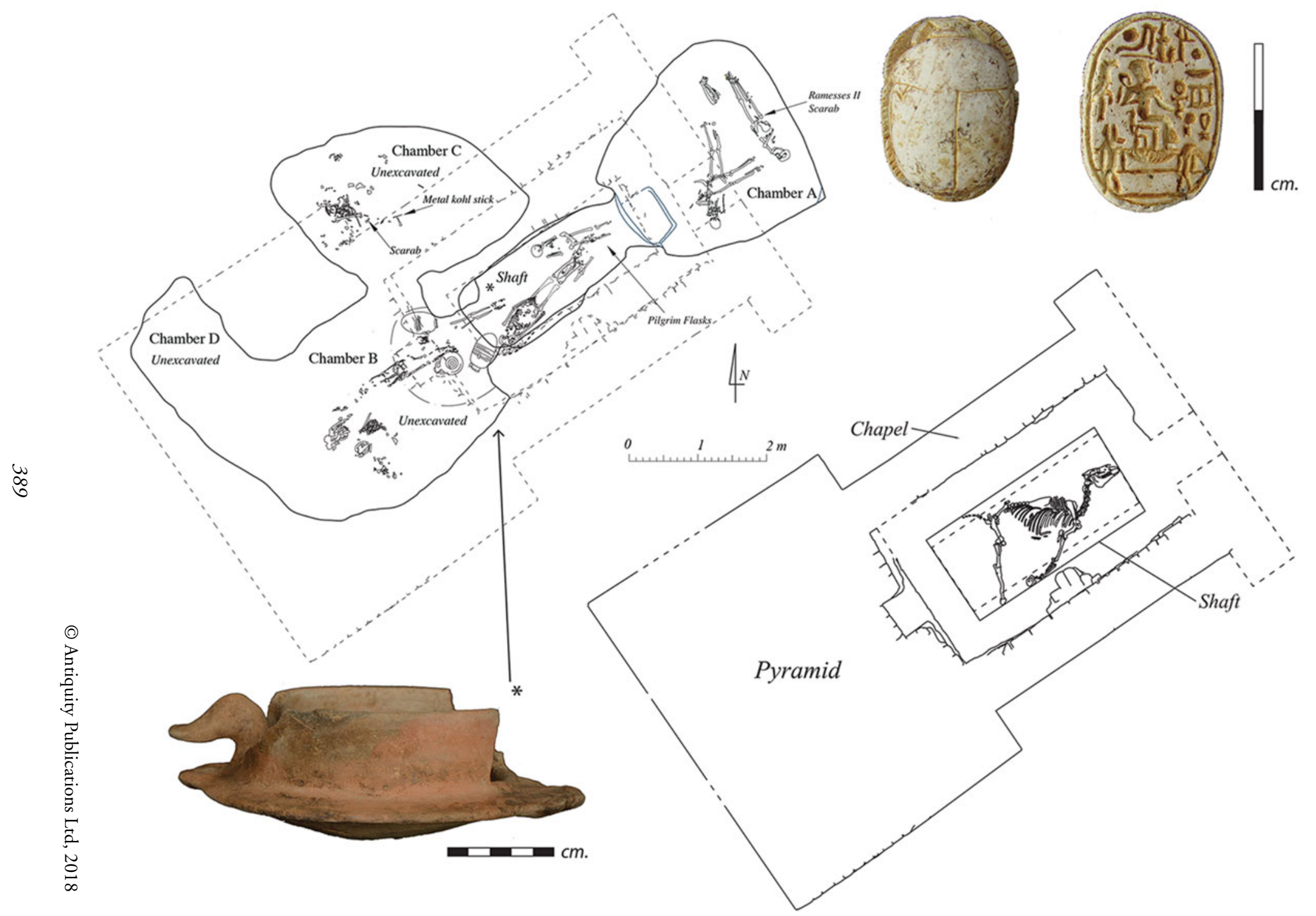




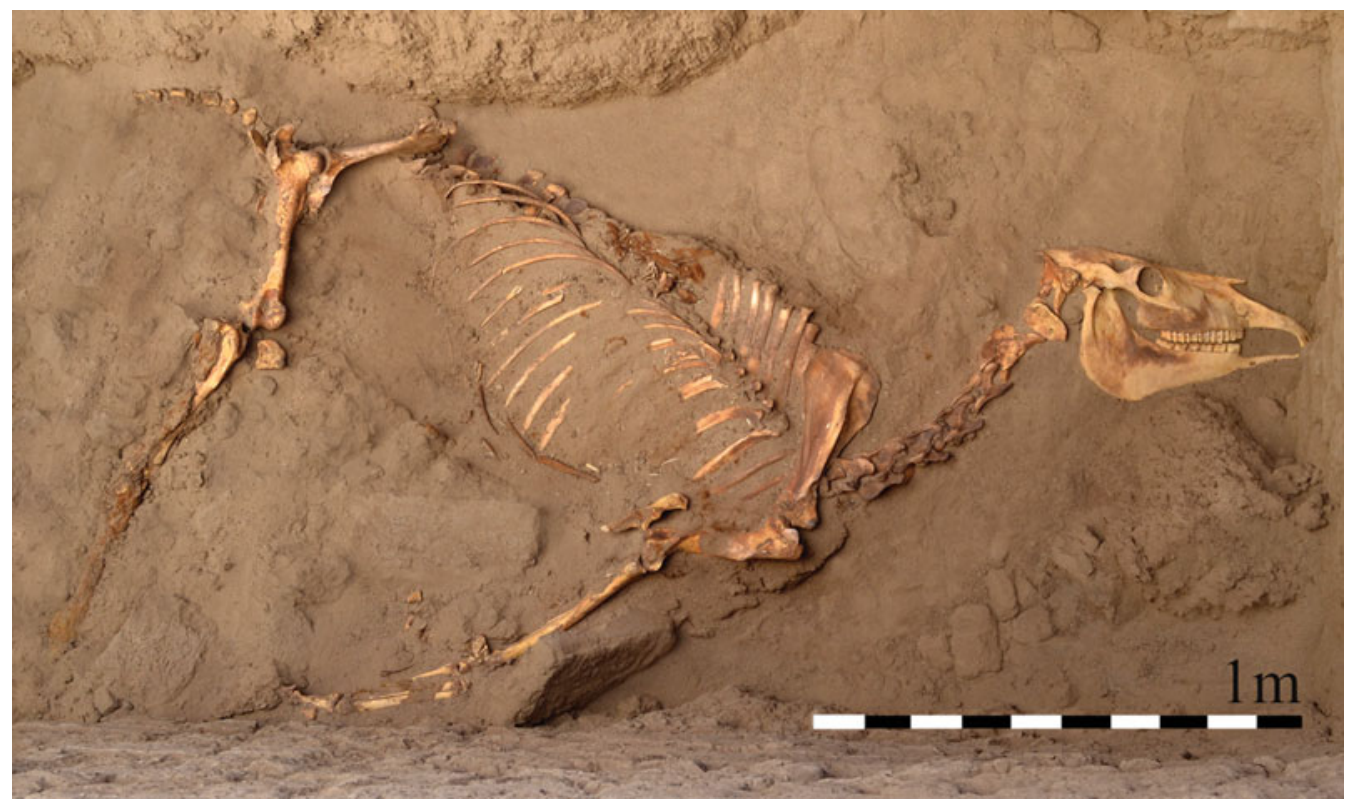

Figure 4. Tombos horse in situ.

The decayed remains of an iron cheekpiece-the lateral portion of the bridle-were also found with the horse (Figure 6). This is one of the earliest pieces of iron found in Nubia. It appears that the tomb was originally constructed and used during the New Kingdom, was looted, fell into ruin and was then

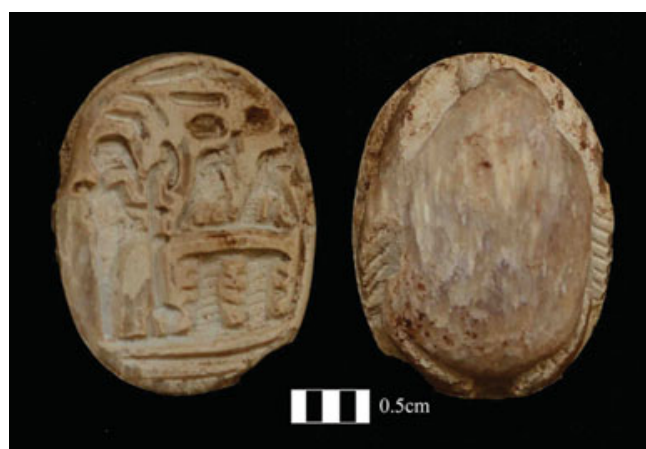

Figure 5. Scarab found in association with the Tombos horse; a figure of Ptah is on the left, facing bird-like Ba's of Re and Osiris. reused during the Third Intermediate Period, when the horse and other burials were intentionally placed in the chapel and shaft. Below the horse, disarticulated human remains were excavated, indicating looting events prior to the equid burial. As a number of intact burials were found at the bottom of the shaft and in the burial chambers, this disturbance was relatively light. The horse burial itself sealed the deposits below, including architectural debris from the collapse of the shaft walls or the chapel that probably derived at least partly from the earlier looting episode(s). The reused tomb shaft with the horse burial was sealed with a series of large granite beams, under which two juvenile human burials were placed. The granite seal was breached in antiquity, perhaps to access the human remains placed above the horse, although the horse itself was undisturbed by this activity.

(C) Antiquity Publications Ltd, 2018 
Osteological analysis of the horse indicates that the individual was probably female and died at 12-15 years of age (determined from pelvic morphology, the presence of vestigial canines and dental wear). Bilateral os-

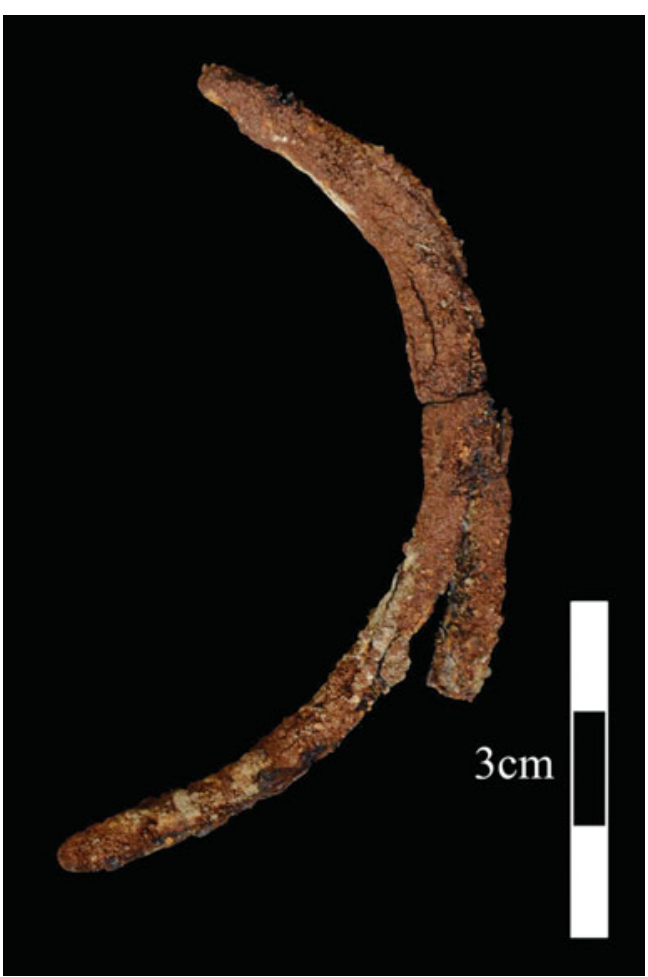

Figure 6. Iron cheekpiece. teoarthritis of the elbow and proximal phalanges suggests that the horse engaged in regular and somewhat strenuous physical activity. Further, degeneration to the first ribs and first thoracic vertebra are evidence for the use of a chariot saddle harness, which sits directly at the base of the neck and imparts particular stress on this area of the skeleton. Although ancient Egyptian artwork and texts depict male horses pulling chariots, the mare belonging to Senenmut (an Eighteenth Dynasty architect and close advisor to Queen/King Hatshepsut) also had skeletal indications of a saddle harness (see the Thebes burial in the OSM; Chard 1937; see also Boessneck 1970). Additionally, recent excavations at Tell el Dab'a yielded the burial of a mare from the early New Kingdom (originally dated to the Hyksos Period but revised to the early Eighteenth Dynasty, Bietak n.d.). It is thus probable that mares were used to pull chariots, but were not referred to in texts or art.

Alternatively, the Tombos, Tell el Dab'a and Senenmut mares may be exceptions to general practice.

The significance of these burials can be addressed through three overlapping themes: object, capital and symbol. In the context of the socio-political shift from colony to independent Nubian state, the Tombos horse and horses in general may have been objects used for labour or warfare, sources of social and economic capital, and, lastly, symbols of an emerging Kushite identity. These categories are, however, not mutually exclusive. Framing the Tombos horse and its funerary context in this way facilitates a more nuanced understanding of the species' complex entanglement with social, political, economic and ideological processes associated with Nubian state formation.

\section{The horse as object}

The horse can be viewed as an object that facilitated transportation and possibly warfare. Bilateral osteoarthritis suggests that the Tombos horse was physically active throughout its life, and degenerative changes to the thorax indicate that this may have involved pulling a chariot. It is unlikely that the horse was being used as a source of labour; Clutton-Brock

(C) Antiquity Publications Ltd, 2018 
(1992: 154) notes that archaeological, textual and artistic evidence for horse plough and traction is not present until $c$. AD 1100 . Before then, oxen and donkeys would have been used as beasts of burden (Clutton-Brock 1992: 68). The Tombos horse may have been employed as a mode of fast communication or trade between Egypt and Nubia via the desert oasis routes, or between Nubian population centres (Figure 1; Edwards 2004).

Given the prominence of chariotry in the Bronze and Iron Ages, it is more probable that the horse played an active military role. Conventionally, the fall of the New Kingdom Empire has been attributed to political fragmentation, the collapse of the Late Bronze Age in the circum-Mediterranean region and environmental change, leading to Egypt's gradual decline and eventual withdrawal from Syro-Palestine and Nubia (Trigger 1976). Historical records, however, make it clear that the Egyptians did not, in fact, abandon their Nubian colonies; rather, Panhesy, the last Viceroy of Kush (Nubia), led a rebellion against the Pharaoh Ramses XI at the close of the New Kingdom (c. 1079 BC; Morkot 2000). Although this uprising was ultimately thwarted by Herihor, the general and High Priest of Amun, Panhesy was never completely defeated, instead retreating back into Nubia with the colonial army. The archaeological evidence of continuity into the early Napatan Period at former colonial centres such as Tombos and Amara West supports this historical picture, contradicting the old Egyptological model of withdrawal and abandonment in the aftermath of the colony's break from Egypt (Smith \& Buzon 2014). Instead of a reversion to competing 'chiefdoms', this evidence indicates a more nuanced pattern of secondary state formation. This state was built on a combination of the surviving New Kingdom colonial infrastructure (which, it is becoming increasingly apparent, remained largely intact) and older indigenous political institutions represented at sites such as Kurru and Hillat el Arab, both of which have horse burials (cf. Török 2009: 291-309). The Tombos horse is too young to have been directly involved in Panhesy's coup attempt, but it may have been used in other undocumented military endeavours, or was trained to do so. Placing the Tombos horse in this larger Bronze Age context speaks to a continuity of Nubian military prowess and independence that probably served as a foundation for the Kushite state.

\section{The horse as capital}

While osteoarthritis of the Tombos horse suggests that it served a functional role, its funerary context indicates that it was much more than a utilitarian device. During the New Kingdom, Tombos probably served Egypt as a colonial administrative and control centre, ensuring the collection of taxes, gold and tribute. With the decline of the New Kingdom, Tombos and other similar communities entered a period of social, economic and political transition. The people of Tombos may have turned to alternative means of production and trade, independent of imperial demands. There is archaeological and human skeletal evidence to suggest that the inhabitants of Tombos began quarrying local granite resources during the Third Intermediate/Napatan Periods (Dunham 1947; Schrader 2013; Schrader $\&$ Buzon 2017). They may have also been breeding, training and trading horses (Dalley 1985; Morkot 2000). The Assyrians wrote about the superiority of the Kushite horse as early as 729 BC (Heidorn 1997). In this light, the horse can be viewed as a potential source of economic and social capital-a means of maintaining Tombos' prosperity and prominence (C) Antiquity Publications Ltd, 2018 
in a post-colonial setting. The specialisation in horse breeding/training would have included investments both in the individual animals and in developing an international reputation. These socio-economic processes would have produced skilfully trained and biologically adapted animals, thereby increasing the value of the Nubian horse in domestic and foreign markets. That the Nubians were known for their superior horses would have in turn imparted a degree of social capital — those who owned, or were affiliated with, horses may have been considered elite.

The grave goods associated with the Tombos horse (iron cheekpiece, scarab) and the burial context of the animal (intentional burial, shroud, reused pyramid tomb) support these socio-economic interpretations. The cheekpiece is particularly important as it represents one of the earliest, if not the earliest, securely dated examples of iron in Nubia. This is significant due to its metallurgical and technological implications, but also because such a rare and expensive item was made specifically for a horse.

It was generally thought that iron was first produced in Nubia during the late Napatan Period (fifth to sixth centuries BC), but not well established until the Meroitic Period (300 BC-AD 350; Shinnie \& Kense 1982; Tylecote 1982; Rehren 2001). A UCL-Qatar project investigating iron production at Meroë and other sites is pushing back the date of initial iron smelting in Africa. This research, in addition to archaeological findings from Tombos, contradicts the idea that the Nubian-Egyptian armies who fought the Assyrians were poorly equipped (Humphris \& Rehren 2014). Other early iron artefacts (including weapons) recovered from a Twenty-Fifth Dynasty (c. 716-664 BC) burial at Tombos suggest that while iron was limited and of great value, it was available to the contemporaneous elite and military personnel (see Smith 2008). Just as granite was manipulated through quarrying, so too was the horse altered through training and breeding. Taking advantage of both these resources probably aided the establishment and growth of the Kushite state. This economic capital also translated to social capital, evidenced by the funerary context of the Tombos horse, which ties it to memories of an elite Egyptian colonial past, when horses and chariotry were also valued.

\section{The horse as symbol}

Lastly, we explore the concept that the horse was a symbol of Kushite identity, which would be evoked 150 years after the Tombos horse in royal horse burials of the Twenty-Fifth Dynasty. In $c .727$ BC, Kushite King Piankhi conquered an Egypt divided by rival dynasts, founding the Twenty-Fifth Dynasty of Egypt and consolidating a territory that extended from the Mediterranean to the Fifth Cataract (Edwards 2004). Kushites legitimated this northward expansion by deeming themselves the 'saviours' of Egyptian civilisation, and personified this image through Egyptian-style dress, deity worship and pyramid tombs. If a closer look at Kushite cultural practices is taken, however, we find that they did not copy Egyptian mores wholesale; rather, Napatan rulers modified select cultural conventions by blending Egyptian and Nubian conceptions of identity (Smith 2013). While Napatan Period artistic imagery used Egyptian motifs, gods from the Egyptian pantheon were selectively worshipped in Kushite Nubia. For example, Amun-Re, with Egyptian theological roots in creation, fertility and solar rebirth, was consistently portrayed in Nubia as a 
ram-a symbol of a solar deity for the Nubian people since the pre-colonial Kerma period (Török 2002: 10-16). Similarly, Kushite rulers were buried in pyramid structures, an iconic symbol of Egyptian funerary ritual. Kushite pyramids had a greater slope modelled on the monuments of New Kingdom colonial officials, as were those at Tombos, rather than on the older Egyptian royal pyramids. These smaller Kushite royal monuments can thus be seen as a modified cultural symbol that was Egyptian-influenced yet became distinctly Nubian (Török 1997: 118-21; Smith 2008; cf. Silliman 2009).

We suggest that horse burials should be included in this adaptive Kushite repertoire. While horses were used for elite sport, hunting and military purposes in New Kingdom Egypt, they were only rarely formally buried. Conversely, the Kushite kings of the TwentyFifth Dynasty incorporated horse burials as an important part of their commemoration of the royal dead. Beyond the royal cemetery, the significance of horses in Kushite culture is evidenced by Piankhi's victory stela, the temple of Amun at Gebel Barkal and the Temple of Taharqo at Kawa. As Morkot (2000) argues, the vast majority of Egyptian and Nubian citizens were illiterate; incorporating horse iconography into statements of state policy, conquest and worship would have provided a visual reminder of the horse as a symbol of power, status and Kushite culture. We argue that the horse, as a symbol of Kushite identity, was adopted early in the state-formation process. The horse burial from Tombos, dating to the early Third Intermediate Period (c. 949 BC), illustrates this point. Mallory-Greenough (2005) argues that New Kingdom examples, such as those at Buhen and Soleb, cannot be seen as an antecedent of later sacrificial burials due to the lack of ceremonial burial and the absence of tack and ornamentation (with the exception of the horse buried at Thebes, which was interred with a linen shroud; Boessneck 1970). The Tombos ceremonial burial containing tack and ornamentation appears to foreshadow the later royal horse burials.

As Nubia emerged from Egyptian colonial rule, Tombos and other contemporaneous communities can be viewed as nodes of social creativity wherein post-colonial Nubian identity was being reworked. At Tombos, this included the continuation of interwoven Egypto-Nubian burial practices (both flexed and supine burials, and pyramids), as well as the revival of traditional Nubian practices (tumulus structures and bed burials). Earlier monuments, such as the pyramid in which the horse was buried, were adapted and reused, as were structural materials (i.e. mud-bricks and stonework) and artefacts (e.g. scarabs) from the colonial era. These acts embody commemoration of the past, but also evoke notions of a new identity that integrated both Egyptian and Nubian cultural practices (Connerton 1989; Smith \& Buzon 2014). The scarab found in association with the horse exemplifies how this post-colonial community selected elements of Egyptian and Hyksos culture and transformed them into an identity. The face of the scarab is engraved with the Egyptian god Ptah, who is associated with creation. The people of Third Intermediate Period Tombos were actively blending Egyptian theology (Ptah), materiality (scarab) and fauna (horse) into the novel practice of horse reverence through adorned burial. The fact that the horse was interred in such a ceremonious manner suggests that it was not only important, but may have also been imbued with a degree of personhood (Hill 2013). The horse burials at Hillat alArab, despite being poorly preserved, also evidences other Third Intermediate Period communities engaging in similar acts. The culmination of these hybrid cultural practices, including ornate horse burials, is seen 150 years later with the emergence of the Kushite state.

(C) Antiquity Publications Ltd, 2018 


\section{Conclusions}

The funerary context of the Tombos horse and the osteological analysis suggest that this individual was of importance to the community. Beyond being a functional object, this horse may have served as a form of capital in a period of post-colonial regeneration and as a symbol of status tied to emerging statehood. The combination of burial context and grave goods suggests that the practice and meaning behind burying horses was different at Third Intermediate Period Tombos to that in Egypt or Nubia during the New Kingdom. It was during the Third Intermediate Period that Tombos and other similar Nubian communities were formulating the social, economic and political basis of the Napatan state. That no other animal burials have been found at Tombos to date reinforces the argument that horses were conceptualised as meaningful beings, which afforded burial rights more akin to humans than fauna. The chronological placement of the Tombos horse-securely in the early Third Intermediate Period-provides an excellent segue between the scattered equid burials of the New Kingdom and the distinct equid veneration of the Twenty-Fifth Dynasty. We suggest that the horse factored into the emergence of Napatan ideology and identity, which was highly ritualised by $c .750 \mathrm{BC}$-as evidenced by the royal burials at el Kurru. From this perspective, we can view the formation of many of the core aspects of Kushite identity as initially appearing in communities such as Tombos, and through time adopted by the state.

\section{Acknowledgements}

We would like to thank the Sudan National Corporation of Antiquities and Museums (NCAM) and its General Director, Abdel-Rahman Ali, for facilitating our ongoing excavations at Tombos and the broader Third Cataract region. Further, the guidance, hard work and friendship of El-Hassan Ahmed Mohammed, Director of Fieldwork for NCAM, Julie Anderson, David Edwards, Ali Osman M. Salih, Bruce Williams and Nadejda Reshetnikova have been invaluable. We would like to thank all of those who helped to excavate the horse and the remains below it, as well as the community of Tombos. The excavation was supported by grants from the National Science Foundation (BCS-0917824 and 0917815), the National Geographic Society, the Division of Social Sciences and Academic Senate, University of California, Santa Barbara, Purdue University and the Schiff-Giorgini Foundation.

\section{References}

Arbuckle, B.S. \& S.A. McCarty (ed.). 2014. Animals and inequality in the ancient world. Boulder: University Press of Colorado. https://doi.org/10.5876/9781607322863

Argent, G. 2010. Do the clothes make the horse? Relationality, roles, and statuses in Iron Age Inner Asia. World Archaeology 42: 157-74. https://doi.org/10.1086/506288

BADAWY, A. 1968. A history of Egyptian architecture. Berkeley: University of California Press.

BEN-Tor, D. 1989. The scarab: a reflection of ancient Egypt. Jerusalem: Israel Museum.

BiETAK, M. n.d. The palatial precinct at the Nile branch (area $\mathrm{H})$. Available at: http://www.auaris.at/html/ez_helmi_en.html (accessed 2 November 2017).
Boessneck, J. 1970. Ein altägyptisches pferdeskelett. Mitteilungen des Deutschen Archäologischen Instituts Abteilung Kairo 26: 43-47.

- 1976. Tell el-Dab'a III. Die tierknochenfunde 1966-1969. Denkschriften der Österreichischen Akademie der Wissenschaften 5: 21-49.

Boessneck, J. \& A. von Den Driesch. 1992. Tell el-Dabaa VII. Veinna: ÖAW.

BöKÖNYI, S. 1993. Two horse skeletons from the cemetery of Kurru, northern Sudan. Acta Archaeologica Academiae Scientiarum Hungaricae 45: 301-16.

Bronk Ramsey, C. 2009. Bayesian analysis of radiocarbon dates. Radiocarbon 51: 337-60. https://doi.org/10.1017/S0033822200033865

Buzon, M. 2006. Biological and ethnic identity in New Kingdom Nubia. Current Anthropology 47: 683-95. https://doi.org/10.1086/506288

(C) Antiquity Publications Ltd, 2018 
Buzon, M., S.T. Smith \& A. Simonetti. 2016. Entanglement and the formation of ancient Nubian Napatan state. American Anthropologist 118: 284-300. https://doi.org/10.1111/aman.12524

ChaIx, L. 2006. The animal remains, in I. Vincentelli (ed.) Hillat El-Arab: 187-230. Oxford: Archaeopress.

Chard, T. 1937. An early horse skeleton. Journal of Heredity 28: 317-19. https://doi.org/10.1093/ oxfordjournals.jhered.a104395

Clutton-Brock, J. 1974. The Buhen horse. Journal of Archaeological Science 1: 89-100. https://doi.org/10.1016/0305-4403(74)90019-3

- 1992. Horse power. Cambridge (MA): Harvard University Press.

Connerton, P. 1989. How societies remember. Cambridge: Cambridge University Press. https://doi.org/10.1017/CBO9780511628061

DALLEY, S.M. 1985. Foreign chariotry and cavalry in the armies of Tiglath-pileser III and Sargon II. Iraq 47: 31-48.

DEFrance, S.D. 2009. Zooarchaeology in complex societies: political economy, status, and ideology. Journal of Archaeological Research 17: 105-68. https://doi.org/10.1007/s10814-008-9027-1

Dunham, D. 1947. Four Kushite colossi in the Sudan. Journal of Egyptian Archaeology 33: 63-65. https://doi.org/10.2307/3855440

- 1950. The royal cemeteries of Kush. Cambridge (MA): Harvard University Press.

EDWARDS, D.N. 2004. Nubian past: an archaeology of the Sudan. London \& New York: Routledge.

Heidorn, L.A. 1997. The horses of Kush. Journal of Near Eastern Studies 56: 105-14. https://doi.org/10.1086/468525

Hill, E. 2013. Archaeology and animal persons: toward a prehistory of human-animal relations. Environment and Society 4: 117-36. https://doi.org/10.3167/ares.2013.040108

Humphris, J. \& T. ReHren. 2014. Iron production and the kingdom of Kush: an introduction to UCL Qatar's research in Sudan, in A. Lohwasser \& P. Wolf (ed.) Ein forscherleben zwischen den welten. Zum 80. Geburtstag von Steffen Wenig. Berlin: Sonderheft Mitteilungen der Sudanarchäologischen Gesellschaft zu Berlin.

LENOBLE, P. 1994. Une monture pour mon royaume: sacrifices triomphaux de chevaux et de méhara d'El Kurru à Ballana. Archéologie du Nil Moyen 6: 107-30.

Littauer, M.A. \& J.H. Crouwel. 1985. Chariots and related equipment form the tomb of Tut'ankhamun. Oxford: Griffith Institute.

Macadam, M.F.L. 1955. The temples of Kawa. London: Oxford University Press.
Mallory-Greenough, L. 2005. The horse burials of Nubia. Journal of the Society for the Study of Egyptian Antiquities 32: 105-10.

Martin, G. 1991. The hidden tombs of Memphis. London: Thames \& Hudson.

Mовкот, R.G. 2000. The black pharaohs. London: Rubicon.

- 2013. From conquered to conqueror: the organization of Nubia in the New Kingdom and the Kushite administration of Egypt, in J.C.M. García (ed.) Ancient Egyptian administration: 911-64. Leiden: Brill.

O’Day, S.J., W. VAn NeEr \& A. Ervynck (ed.). 2004. Behaviour behind bones: the zooarchaeology of ritual, religion, status and identity. Oxford: Oxbow.

Olsen, S.L. 2006. Introduction, in S.L. Olsen, S. Grant, A.M. Choyke \& L. Bartosiewicz (ed.) Horses and humans: the evolution of human-equine relationships (British Archaeological Reports International series 1560): 1-10. Oxford: British Archaeological Reports.

Olsen, S.L. \& C. Culbertson. 2010. A gift from the desert: the art, history and culture of the Arabian horse. Lexington (KY): International Museum of the Horse.

Quibell, J.E. \& A. Olver. 1926. An ancient Egyptian horse. Annales du Service des Antiquités de l'Egypte 26: 172-76.

Raulwing, P. \& J. Clutton-Brock. 2009. The Buhen horse: fifty years after its discovery (1958-2008). Journal of Egyptian History 2(1-2): 1-106. https:// doi.org/10.1163/187416509X12492786609122

Rehren, T. 2001. Meroe, iron and Africa. Mitteilungen der Sudanarchaeologischen gesellschaft 12: 102-109.

Reimer, P.J., E. Bard, A. Bayliss, J.W. Beck, P.G. Blackwell, C. Bronk Ramsey, C.E. Buck, H. Cheng, R.L. Edwards, M. Friedrich, P.M. Grootes, T.P. Guilderson, H. Haflidason, I. Hajdas, C. Hatté, T.J. Heaton, D.L. Hoffmann, A.G. Hogg, K.A. Hughen, K.F. Kaiser, B. Kromer, S.W. Manning, M. NiU, R.W. Reimer, D.A. Richards, E.M. Scott, J.R. Southon, R.A. Staff, C.S.M. Turney \& J. VAN DER PLICHT. 2013. IntCal13 and Marine13 radiocarbon age calibration curves $0-50,000$ years cal BP. Radiocarbon 55: 1869-87. https://doi.org/10.2458/azu_js_rc.55.16947

RiLly, C. 2001. Une nouvelle interprétation du nom royal Piankhy. Bulletin de l'Institut Français d'Archéologie Orientale 101: 351-68.

Russell, N. 2012. Social zooarchaeology. Cambridge: Cambridge University Press.

SäVE-SöDERBERGH, T. 1951. The Hyksos rule in Egypt. Journal of Egyptian Archaeology 37: 53-71. https://doi.org/10.2307/3855157 


\section{Symbolic equids and Kushite state formation}

SChrader, S. 2013. Bioarchaeology of the everyday: analysis of activity patterns and diet in the Nile Valley. Unpublished PhD dissertation, Purdue University.

Schrader, S. \& M. Buzon. 2017. Everyday life after collapse: a bioarchaeological examination of entheseal changes and accidental injury in post-colonial Nubia. Bioarchaeology International 1: 19-34. https://doi.org/10.5744/bi.2017.1000

Shinnie, P.L. \& F.J. Kense. 1982. Meroitic iron working. Meroitica 6: 17-28.

Silliman, S.W. 2009. Change and continuity, practice and memory: Native American persistence in colonial New England. American Antiquity 74: 211-30. https://doi.org/10.1017/S0002731600048575

Sмiтн, S.T. 2003. Wretched Kush: ethnic identities and boundaries in Egypt's Nubian empire. London: Routledge.

- 2008. Tombos and the transition from the New Kingdom to the Napatan Period in Upper Nubia, in W. Godlewski \& A. Latjar (ed.) Between the cataracts: 95-115. Warsaw: WUW.

- 2013. Revenge of the Kushites: assimilation and resistance in Egypt's New Kingdom empire and Nubian ascendancy over Egypt, in G. Areshian (ed.) Empires and complexity: 84-107. Los Angeles (CA): Cotsen Institute of Archaeology at UCLA.
Smith, S.T. \& M.R. Buzon. 2014. Identity, commemoration, and remembrance in colonial encounters: burials at Tombos during the Egyptian New Kingdom Nubian empire and its aftermath, in B.W. Porter \& A.T. Boutin (ed.) Remembering the dead in the ancient Near East: 185-216. Boulder: University Press of Colorado.

Spalinger, A. 1981. Notes on the military in Egypt during the $\mathrm{XXV}^{\text {th }}$ Dynasty. Journal of the Society for the Study of Egyptian Antiquities 11: 37-58.

- 2005. War in ancient Egypt. Malden (MA): Blackwell.

SPENCER, N. 2014. Creating and re-shaping Egypt in Kush: responses at Amara West. Journal of Ancient Egyptian Interconnections 6: 42-61.

Тӧвӧк, L. 1997. The kingdom of Kush. Handbook of the Napatan-Meroitic civilization. Leiden: Brill.

- 2002. The image of the ordered world in ancient Nubian art. Leiden: Brill.

-2009 . Between two worlds: the frontier region between ancient Nubia and Egypt, 3700 BC-AD 500 (Probleme der Ägyptologie 29). Leiden: Brill.

Trigger, B. 1976. Nubia under the pharaohs. Boulder (CO): Westview.

Tylecote, R.F. 1982. Metal working at Meroe, Sudan. Meroitica 6: 29-49.

Received: 9 January 2017; Accepted: 19 April 2017; Revised: 9 May 2017 